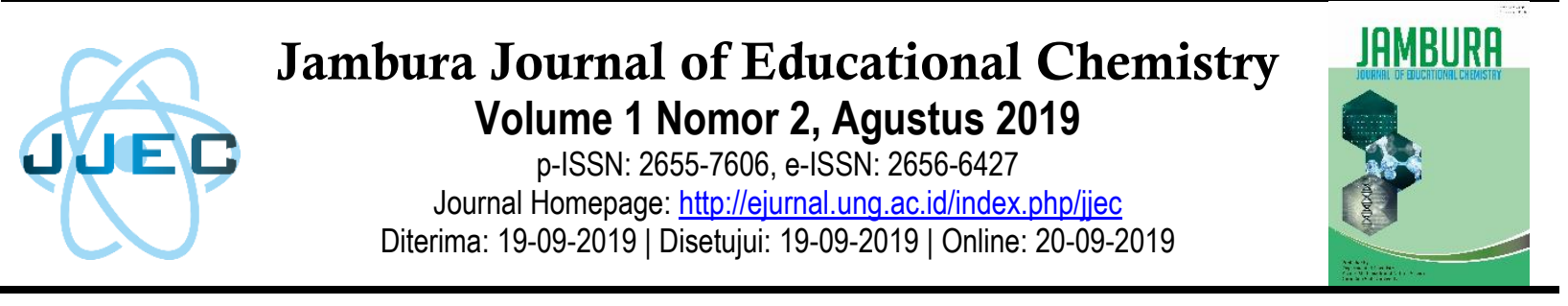

\title{
Studi Komparasi Kemampuan Berpikir Kritis Siswa Menggunakan Model Pembelajaran Problem Based Learning dan Discovery Learning Pada Materi Larutan Penyangga di Kelas XI SMA Negeri 1 Telaga
}

\author{
Ni Wayan Desni1 ${ }^{1}$ Mangara Sihaloho² ${ }^{2}$ dan Masrid Pikoli3 \\ 1,2,3Program Studi Pendidikan Kimia, Fakultas Matematika dan IPA, Universitas Negeri Gorontalo \\ e-mail: m.sihaloho@rocketmail.com
}

\begin{abstract}
Abstrak
Penelitian ini bertujuan mengetahui kemampuan berpikir kritis siswa yang mengikuti model pembelajaran Problem Based Learning (PBL) dan Discovery Learning pada materi Larutan Penyangga di Kelas XI SMA Negeri 1 Telaga. Populasi dalam penelitian ini adalah seluruh siswa kelas XI SMA Negeri 1 Telaga dan diambil 2 kelas sebagai sampel. Jenis penelitian ini adalah Quasi experimental dengan desain Pretest-Postest Nonequivalent Control Grup. Instrumen penelitian berupa tes berpikir kritis dalam bentuk esay yang sudah di uji validitas dan reliabilitas. Tes yang digunakan berstatus valid dengan reliabilitas $r=0,72$ (kategori tinggi). Analisis data menggunakan uji $\mathrm{F}$ untuk menguji hipotesis penelitian. Hasil analisis data menunjukkan bahwa pada taraf signifikan $\alpha=0,05$ diperoleh nilai $\mathrm{F}_{\text {hitung }}=6,68>\mathrm{F}_{\text {tabel }}=3,99$ sehingga $\mathrm{H}_{0}$ berada pada daerah penolakan atau terima $\mathrm{H}_{1}$. Sehingga dapat disimpulkan bahwa model pembelajaran Problem Based Learning memberikan pengaruh lebih baik dibandingkan Discovery Learning terhadap kemampuan berpikir kritis siswa.
\end{abstract}

Kata Kunci: Discovery Learning; Problem Based Learning; Kemampuan Berpikir Kritis.

\section{PENDAHULUAN}

Pendidikan menjadi faktor paling berpengaruh terhadap perkembangan hidup manusia, hal ini disebabkan pendidikan adalah suatu wadah aktivitas dalam memperoleh dan menyampaikan ilmu pengetahuan (knowledge) yang dimungkinkan dapat meneruskan budaya yang dianut untuk generasi berikutnya. Pendidikan adalah hal pokok yang akan menopang kemajuan suatu bangsa. Kemajuan suatu bangsa dapat diukur dari kualitas dan sistem pendidikan yang ada, tanpa pendidikan, suatu negara akan jauh tertinggal dari negara lain.

Proses inkuiri ilmiah memiliki tujuan untuk menumbuhkan kemampuan berpikir, bekerja, bersikap ilmiah, dan berkomunikasi sebagai aspek penting kecakapan hidup (Badan Standar Nasional
Pendidikan, 2006). Pembelajaran kimia menekankan pada pemberian pengalaman belajar secara langsung dengan melalui penggunaan dan pengembangan keterampilan proses serta sikap ilmiah, misalnya kemampuan berpikir kritis.

Berdasarkan standar isi buku satuan pendidikan dasar dan menengah, mata pelajaran kimia perlu diajarkan untuk tujuan yang lebih khusus yaitu, membekali peserta didik dengan pengetahuan, pemahaman belajar dan kemampuan yang dipersyaratkan untuk memasuki jenjang perguruan tinggi untuk mengembangkan ilmu sains dan teknologi.

Kemampuan berpikir kritis merupakan salah satu kemampuan yang harus dicapai dalam proses pembelajaran. Hal ini sesuai dengan Permendikbud Nomor 23 Tahun 2016 tentang Standar Penilaian 
berikut: Salah satu keterampilan yang diharapkan menjadi output dalam proses pembelajaran yang berlangsung adalah keterampilan berpikir kritis.

Kemampuan berpikir kritis siswa sangat penting dalam pencapaian proses pembelajaran, namun pada kenyataannya kemampuan berpikir kritis siswa masih tergolong rendah. Hal ini dapat dilihat dari hasil survey Programme for International Student Assesment (PISA) pada tahun 2015 bahwa skor rata-rata kemampuan sains siswa Indonesia adalah sebesar 403. Skor rata-rata yang ditetapkan oleh PISA adalah sebesar 493 (OECD, 2016). Sehingga dapat dilihat bahwa skor indonesia masih di bawah dari standar yang di tetapkan.

Berdasarkan hasil wawancara dengan guru di sekolah SMA Negeri 1 Telaga, diperoleh informasi bahwa siswa masih sering mengalami kesulitan meginterpretasi masalah dan menentukan strategi dalam penyelesaian soal, sebab siswa kurang memperhatikan dan pasif dalam kegiatan pembelajaran. Hal ini berdampak pada perkembangan kemampuan berpikir kritis siswa, maka perlu diterapkan model pembelajaran yang membuat siswa aktif dalam pembelajaran dikelas, dan lebih banyak memiliki kesempatan untuk menganalisis suatu masalah, mengungkapkan gagasan yang ia miliki serta mendengarkan gagasan dari orang lain, serta dapat mengeksplorasi pengetahuan siswa.

Dalam penelitian yang sudah pernah dilakukan Oktaviana et al., (2016) dan Sujatmika et al., (2018) mendapatkan hasil bahwa penggunaan model pembelajaran Problem Based Learning (PBL) dapat meningkatkan kemampuan berpikir kritis siswa. Begitu juga halnya dengan penelitian yang telah dilakukan Agustya (2018) dan Nikmah et al., (2018) membuktikan bahwa model pembelajaran Discovery Learning dapat meningkatkan kemampuan berpikir kritis siswa khususnya pada mata pelajaran kimia.

Berdasarkan hasil-hasil tersebut, maka dipandang perlu untuk mengetahui kemampuan berpikir kritis siswa dan pengaruh-pengaruh pembelajaran Problem Based Learning dengan Discovery Learning pada materi Larutan Penyangga terhadap berpikir kritis.

Tujuan penelitian dalam penelitian ini adalah untuk mengetahui pengaruh pembelajaran Problem Based Learning dengan Discovery Learning terhadap kemampuan berpikir kritis siswa pada materi Larutan Penyangga di Kelas XI SMA Negeri 1 Telaga.

Kemampuan berpikir kritis adalah kemampuan berpikir yang dimiliki seseorang dalam membuat keputusan yang autentik dan bertanggung jawab yang mempengaruhi hidup seseorang (Redhana, 2015). Menurut Surya (2014) dalam kajian psikologi berpikir di definisikan sebagai suatu proses mental dalam mengeksplorasi peta pengalaman yang merupakan suatu keterampilan bertindak dengan kecerdasan sebagai sumber daya penalaran. Sedangkan menurut Johnson (2007) berpikir kritis merupakan sebuah proses sistematis yang memungkinkan siswa untuk merumuskan, mengevaluasi keyakinan dan pendapat mereka sendiri.

Berdasarkan beberapa pendapat di atas, maka dapat dikemukakan bahwa berpikir merupakan proses mental atau suatu kegiatan mental yang bertujuan untuk memperoleh pengetahuan dalam memecahkan suatu masalah yang dihadapi. dapat dikatakan bahwa proses mental ini berlangsung antara stimulus dan respon.

Problem Based Learning merupakan suatu proses pembelajaran yang menyuguhkan berbagai situasi pemasalahan yang dapat dipercaya dan berfungsi bagi siswa, sehingga masalah itu dapat dijadikan batu loncatan untuk melakukan penelusuran (investigasi) dan penelitian (Sujana, 2014).

Model Discovery Learning merupakan suatu model pembelajaran yang dikembangkan oleh Jerome Bruner. Konsep dasar pembelajaran ini adalah siswa didorong untuk belajar menemukan sendiri, melalui kegiatan aktif siswa untuk memahami konsep-konsep dan prinsip-prinsip yang didukung pengalaman-pengalaman belajar sebelumnya serta menghubungkan pengalamannya dengan konsep-konsep baru yang mereka pelajari di bawah bimbingan guru (Irham \& Wiyani, 2013).

Terdapat beberapa penelitian yang relevan dengan menggunakan model pembelajaran Problem Based Learning, diantaranya menurut penelitian yang dilakukan Susilo (2012) bahwa terjadi peningkatan kemampuan berpikir kritis siswa yang ditunjukkan dengan hasil pretest dan posttest, yaitu perbedaan hasil belajar siswa sebelum dan sesudah diterapkannya model pembelajaran berbasis 
masalah. Hasil pretest siswa yang diperoleh pada materi berbagai sifat dalam perubahan fisika dan perubahan kimia mendapatkan nilai rata-rata 61,53, dengan persentase $12 \%$ siswa tuntas belajar. Sedangkan nilai posttes memperoleh nilai rata-rata yaitu 80,24 , dengan persentase ketuntasan belajar sebesar $85 \%$.

Menurut penelitian Surya (2014) yang menunjukkan bahwa hasil analisis rata-rata $\mathrm{N}$-gain setiap indikator kemampuan berpikir kritis siswa, peningkatan kelas eksperimen lebih tinggi dari kelas kontrol. Hal tersebut sesuai dengan peningkatan aktivitas belajar yang lebih tinggi pada kelas eksperimen dengan nilai 90,09 sedangkan pada kelas kontrol 79,28.)

Menurut penelitian Zarita et al., (2015) adanya dampak model pembelajaran Problem Based Learning (PBL) dengan pendekatan saintifik terhadap berpikir kritis siswa pada materi Prinsip Archimedes. Kenaikan nilai pretest dan posttest sebesar 23,00 untuk kelas eksperimen dan 11,83 untuk kelas kontrol. Rata-rata $N$-Gain untuk kelas eksperimen termasuk kategori tinggi, yaitu 75\% dan kelas kontrol 28\%.)

Menurut penelitian Kurniati et al., (2017) dinyatakan bahwa (1) Rata-rata kemampuan berpikir kritis peserta didik yang menerima pembelajaran Discovery Learning berbantuan Smart Sticker dalam kelas mencapai nilai lebih dari 65; (2) Siswa yang kemampuan berpikir kritisnya lebih dari 65 dengan pembelajaran Discovery Learning berbantuan Smart Sticker mencapai lebih dari 70\%; (3) Kemampuan berpikir kritis peserta didik yang menerima pembelajaran Discovery Learning berbantuan Smart Sticker lebih baik dibandingkan peserta didik yang menerima pembelajaran Ekspositori; (4) Kemampuan berpikir kritis peserta didik yang menerima pembelajaran Discovery Learning berbantuan Smart Sticker meningkat).

\section{METODE PENELITIAN Jenis Penelitian}

Jenis penelitian ini adalah Quasi experimental dengan desain Pretest-Postest Nonequivalent Control Grup.

\section{Waktu dan Tempat Penelitian}

Penelitian ini dilaksanakan pada semester genap tahun ajaran 2018/2019 dalam waktu \pm 1 bulan . Penelitian ini dilaksanakan di kelas XI SMA Negeri 1 Telaga.

\section{Target/Subjek Penelitian}

Populasi dalam penelitian ini adalah semua siswa kelas XI MIA di SMA Negeri 1 Telaga yang terdiri dari 6 kelas yang berjumlah 162 siswa tahun ajaran 2018/ 2019. Teknik Pengambilan sampel yaitu dengan Simple Random Sampling dan didapat bahwa Kelas XI MIA 5 sebagai kelas eksperimen I yang diajarkan dengan model pembelajaran Problem Based Learning dan kelas XI MIA 4 sebagai kelas eksperimen II yang diajarkan dengan model pembelajaran Discovery Learning.

\section{Prosedur}

Disain yang digunakan adalah pretest posttest nonequivalent control group pada tabel berikut (Sugiono, 2015).

Tabel 1. Pretes-Postes Non Equivalent Control Group Design

\begin{tabular}{cccc}
\hline Kelas & Pretes & Perlakuan & Postes \\
\hline KE1 & $\mathrm{O}_{1}$ & $\mathrm{X}_{1}$ & $\mathrm{O}_{2}$ \\
$\mathrm{KE} 2$ & $\mathrm{O}_{1}$ & $\mathrm{X}_{2}$ & $\mathrm{O}_{2}$ \\
\hline
\end{tabular}

Keterangan:

$\mathrm{O}_{1}=$ Pretes

$\mathrm{O}_{2}=$ Postes

$\mathrm{X}_{1}=$ Perlakuan (model Problem Based Learning)

$\mathrm{X}_{2}=$ Perlakuan (model Discovery Learning)

\section{Teknik Pengumpulan Data}

Teknik pengumpulan data dalam penelitian ini adalah dengan memberikan pretest dan posttest untuk melihat kemampuan siswa sebelum dan sesudah diterapkan model Problem Based Learning dan Discovery Learning.

\section{Teknik Analisis data}

Teknik analisis data yang digunakan dalam penelitian ini penelitian ini digunakan uji anacova. Anacova merupakan salah satu teknik analisis parametrik, sehingga bentuk data yang dianalisis dengan anacova adalah data kuantitatif. Analisis kovarian dilakukan dengan cara yang sama dengan analisis varian, yakni dengan menghitung F. Rumus yang digunakan adalah.

$$
\mathrm{F}^{*}=\frac{R K_{A}^{*}}{R K_{D}^{*}}
$$

Dengan:

$$
\begin{aligned}
& \mathrm{F}^{*}=\text { Koefisien anacova } \\
& R K_{A}^{*}=\text { rata-rata kuadrat standar }
\end{aligned}
$$


$R K_{D}^{*}=$ rata-rata kuadrat dalam

\section{HASIL DAN PEMBAHASAN Hasil Penelitian}

Berdasarkan hasil penelitian diperoleh nilai varians terbesar $S^{2}=54,2178$ dan varians terkecil $S^{2}$ $=43,4545$. Dengan demikian nilai $\mathrm{F}_{\text {hitung }}=1,247$ sedangkan nilai $\mathrm{F}_{\text {tabel }}=1,808$. Artinya kedua varians homogen dan dapat dilakukan uji $\mathrm{F}$.

Tabel 2. Hasil Uji Homogenitas Data Posttest

\begin{tabular}{cccc}
\hline $\begin{array}{c}\text { Data } \\
\text { Sumber }\end{array}$ & F $_{\text {hitung }}$ & F tabel & Kesimpulan \\
\hline KE1 & 1,247 & 1,808 & Homogen \\
KE 2 & 1,247 & 1,808 & Homogen \\
\hline
\end{tabular}

Uji normalitas data dalam penelitian ini menggunakan uji statistik liliefors dengan taraf nyata $\alpha=0,05$. Dalam penelitian ini dikelompokkan menjadi dua bagian yaitu kelas Eksperimen 1 dan kelas Eksperimen 2.

a. Pengujian data kelas eksperimen 1

Berdasarkan hasil postest kelas eksperimen diperoleh nilai $\mathrm{L}_{0}$ sebesar 0,1067 untuk taraf nyata $\alpha=0,05$ dan $\mathrm{n}=33$, nilai $\mathrm{L}_{\text {tabel }}$

sebesar $=0,1542$ Dengan demikian dapat disimpulkan bahwa hipotesis $\mathrm{H}_{0}$ diterima sebab $\mathrm{L}_{0}$ $<\mathrm{L}_{\text {tabel. }}$. Hal ini berarti sampel tersebut berdistribusi normal.

b. Pengujian data kelas eksperimen 2

Berdasarkan hasil postest kelas eksperimen 2 diperoleh nilai $\mathrm{L}_{0}$ sebesar 0,1419 untuk taraf nyata $\alpha=0,05$ dan $\mathrm{n}=33$, nilai $\mathrm{L}_{\text {tabel }}$ sebesar $=0,1542$ Dengan demikian dapat disimpulkan bahwa hipotesis $\mathrm{H}_{0}$ diterima sebab $\mathrm{L}_{0}<\mathrm{L}_{\text {tabel }}$ dan berdistribusi normal dapat dilihat pada Tabel 4.5 berikut.

Tabel 3. Hasil Uji Normalitas Data

\begin{tabular}{cccc}
\hline $\begin{array}{c}\text { Data } \\
\text { Sumber }\end{array}$ & $\mathbf{L}_{\text {hitung }}$ & $\mathbf{L}_{\text {tabel }}$ & Kesimpulan \\
\hline KE 1 & 0,1067 & 0,1542 & Normal \\
KE 2 & 0,1419 & 0,1542 & Normal \\
\hline
\end{tabular}

Setelah data dinyatakan berdistribusi normal maka dilanjutkan dengan pengujian hipotesis. Untuk menguji hipotesis digunakan uji anacova, dan diperoleh nilai $F_{\text {hitung }}=6,68>F_{\text {tabel }}=3,99$ Sehingga dapat disimpulkan bahwa $\mathrm{H}_{0}$ ditolak dan $\mathrm{H}_{1}$ diterima.

\section{Pembahasan}

Pada penelitian ini sebelum dilaksanakan pengumpulan data terlebih dahulu dilakukan uji validasi dan reliabilitas instrumen untuk mengetahui kelayakan dari instrumen yang digunakan. Selanjutnya kedua kelas diberikan perlakuan, untuk kelas eksperimen 1 diberikan perlakuan dengan model pembelajaran Problem Based Learning sedangkan untuk kelas eksperimen 2 diberikan perlakuan yang berbeda yaitu dengan model pembelajaran Discovery Learning.

Selanjutnya kedua sampel diberikan posttest dengan jenis soal yang sama pada pretest. pemberian pretest dan posttes ini adalah untuk mengetahui peningkatan kemampuan berpikir kritis siswa sebelum dan sesudah diajarkan dengan menggunakan dua model di dua kelas yang berbeda. Setelah diperoleh data pretest dan posttest kemudian dilakukan uji hipotesis untuk mengetahui hipotesis penelitian diterima atau tidak, tetapi sebelum dilakukan uji hipotesis terlebih dahulu dilakukan uji normalitas data dan uji homogenitas varians sebagai syarat dalam melakukan uji hipotesis.

Berdasarkan daftar nilai pretest dan postest dari kelas eksperimen 1 dan kelas eksperimen 2, kemudian dilakukan uji normalitas data untuk mengetahui data berdistribusi normal atau tidak. Setelah pengujian normalitas untuk kelas eksperimen 1 dan kelas eksperimen 2 didapat bahwa kedua kelas berdistribusi normal.

Setelah melakukan uji normalitas data, selanjutnya dilakukan uji homogen untuk mengetahui kedua sampel baik eksperimen 1 maupun eksperimen 2 memiliki varians berasal dari populasi yang sama (homogen). Berdasarkan hasil perhitungan homogenitas varians dan normalitas data bahwa kedua sampel berasal dari populasi yang homogen dan berdistribusi normal maka syarat pengujian hipotesis terpenuhi dan pengujian hipotesis dapat dilakukan. Pengujian hipotesis yang digunakan dalam penelitian ini menggunakan teknik analisis kovarians atau anacova.

Hasil analisis anacova pada taraf signifikasi 5\% diperoleh kesimpulan bahwa terdapat perbedaan yang signifikan, yaitu kemampuan berfikir kritis siswa yang diajarkan dengan model pembelajaran Problem Based Learning dengan kemampuan berfikir kritis siswa yang diajarkan dengan model pembelajaran Discovery Learning. Dengan kata 
lain, bahwa model pembelajaran Problem Based Learning memberikan pengaruh positif terhadap kemampuan berfikir kritis siswa. Model pembelajaran Problem Based Learning memberikan kesempatan lebih banyak kepada siswa untuk mencari informasi diberbagai sumber belajar.

Dalam penelitian ini, penggunaan model pembelajaran Problem Based Learning menunjukkan hasil yang lebih positif dibandingkan dengan penggunaan model pembelajaran Discovery Learning yang dapat dilihat dari persentase masingmasing indikator tes siswa. Adapun hasil dari kemampuan berpikir kritis siswa pada kelas eksperimen 1 yang menggunakan model pembelajaran Problem Based Learning dan kelas yang menggunakan model pembelajaran Discovery Learning mengalami peningkatan secara signifikan.

Peningkatan kemampuan berpikir kritis siswa kelas eksperimen 1 dan kelas eksperimen 2 untuk masing-masing indikator dapat dilihat pada gambar berikut:

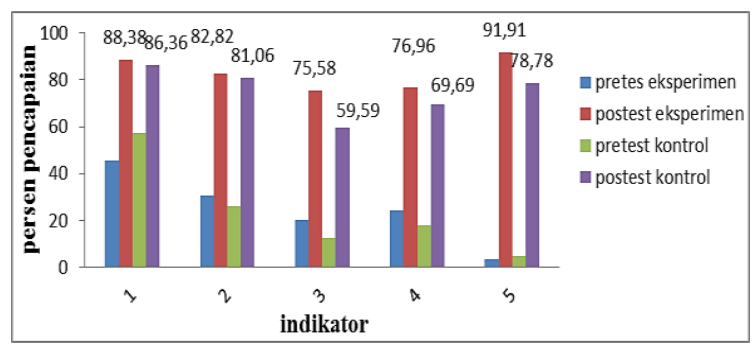

Gambar 1. Kemampuan Berpikir Kritis MasingMasing Indikator pada Kelas Eksperimen 1 dan kelas eksperimen 2

Kemampuan berpikir kritis siswa untuk masing-masing indikator kelas eksperimen 1 lebih tinggi dibandingkan dengan kelas eksperimen 2 yakni model pembelajaran Problem Based Learning lebih berpengaruh besar dari pada Discovery Learning. hal ini karena Problem Based Learning adalah model pembelajaran yang mengarahkan siswa untuk menyelesaikan suatu masalah autentik yang diberikan.

Berdasarkan diagram di atas, untuk eksperimen diperoleh presentase kemampuan berpikir kritis siswa dengan indikator memberikan penjelasan sederhana yakni $88 \%$ dalam hal ini siswa mampu menganalisis argument serta mengidentifikasi alasan yang dikemukakan pada suatu masalah yang diberikan. Berdasarkan indikator kemampuan memberi penjelasan lanjut dengan persentase pencapaian $91,91 \%$ dimana siswa mampu membangun argument yang diperlukan dalam upaya membuktikan suatu pernyataan pada masalah yang telah diberikan. Untuk indikator kemampuan membangun keterampilan dasar yakni memperoleh persentase 75,58\% yaitu siswa mampu memberikan jawaban serta alasan dari pertanyaan atau pernyataan pada suatu permasalahan yang diberikan dengan menyesuaikan sumber terpercaya yang telah mereka dapat. Pada indikator kemampuan mengatur srategi dan teknik yang memperoleh persentase $76,96 \%$ dimana siswa mampu memutuskan dan menentukan solusi jawaban atas pertanyaan yang terdapat pada masalah yang diberikan. Dan untuk indikator menyimpulkan yakni memperoleh nilai persentase $82,82 \%$ dimana dengan memecahkan suatu masalah yang diberikan sehingga siswa mampu mengusulkan kesimpulan yang dapat menjelaskan bukti.

Persentase kemampuan berpikir kritis siswa kelas yang mengikuti model pembelajaran Problem Based Learning lebih baik dibandingkan dengan rata-rata kemampuan berfikir kritis siswa kelas yang mengikuti model pembelajaran Discovery Learning disebabkan adanya perbedaan tahapan pembelajaran yang diterapkan. Dalam kegiatan pembelajaran Problem Based Learning, guru menyajikan suatu masalah yang dapat menantang kemampuan berfikir kritis siswa untuk dapat menyelesaikannya. Sehingga dengan adanya tahapan ini, siswa cenderung merasa tertantang untuk menyelesaikan masalah yang diberikan oleh guru. Sedangkan dalam kegiatan pembelajaran Discovery Learning siswa didorong untuk menemukan sendiri masalah-masalah dan menyelesaikannya. Sehingga siswa cenderung kurang tertarik untuk menemukan masalah dan menyelesaikannya sendiri.

Ada beberapa penelitian yang mendukung penelitian ini, yaitu penelitian menurut (Darmawan, 2018) yang berjudul "Meningkatkan Kemampuan Berpikir Kritis Siswa Melalui Model Pembelajaran Problem Based Learning Pada Materi Larutan Penyangga dikelas XI SMA Negeri 1 Telaga" membuktikan bahwa penggunaan model pembelajaran Problem Based Learning dapat meningkatkan kemampuan berpikir kritis siswa, 
dengan kata lain bahwa penelitiannya menunjukkan hasil positif terhadap peningkatan kemampuan berpikir kritis siswa. Begitu juga penelitian dari (Susilo, 2012) yang berjudul "Pengembangan Model Pembelajaran IPA Berbasis Masalah untuk Meningkatkan Motivasi Belajar dan Berpikir Kritis Siswa SMP" membuktikan bahwa Penggunaan model Problem Based Learning dapat menantang kemampuan siswa untuk menemukan pengetahuan baru bagi siswa itu sendiri.

\section{SIMPULAN}

Berdasarkan permasalahan dan tujuan dalam penelitian ini serta hasil uji hipotesis penelitian dapat disimpulkan bahwa terdapat pengaruh kemampuan berpikir kritis siswa yang mengikuti model pembelajaran Problem Based Learning dengan model pembelajaran Discovery Learning pada materi Larutan Penyangga di kelas XI SMA Negeri 1 Telaga. Kemampuan berpikir kritis siswa yang diajarkan dengan menggunakan model Problem Based Learning lebih efektif dibandingkan dengan model Discovery Learning.

\section{UCAPAN TERIMA KASIH}

Berkat arahan dan dorongan yang selalu diberikan oleh dosen pembimbing bapak Drs. Mangara Sihaloho, M.Pd dan bapak Dr. Masrid Pikoli, M.Pd sehingga artikel ini dapat tersusun dengan baik.

\section{DAFTAR PUSTAKA}

Agustya, D. (2018). Efektivitas Model Pembelajaran Discovery Learning Berbasis Ethnomathematics ditinjau dari kemampuan berfikir kritis siswa. Lampung: Universitas Lampung.

Darmawan. (2018). Meningkatkan Kemampuan Berpikir Kritis Siswa Melalui Model Pembelajaran Problem Based Learning Pada Materi Larutan Penyangga dikelas XI SMA Negeri 1 Telaga. Universitas Negeri Gorontalo.

Irham, M., \& Wiyani, N. A. (2013). Psikologi Pendidikan: Teori dan aplikasi dalam proses pembelajaran. Yogyakarta: Ar-Ruzz Media.

Johnson, E. B. (2007). Contextual teaching and learning: Menjadikan kegiatan belajar mengajar mengasyikkan dan bermakna. Bandung: Mizan Learning Center.
Kurniati, I. W., Pujiastuti, E., \& Kurniasih, A. W. (2017). Model Pembelajaran Discovery Learning Berbantuan Smart Sticker untuk Meningkatkan Disposisi Matematik dan Kemampuan Berpikir Kritis. Kreano, Jurnal Matematika Kreatif-Inovatif, 8(2), 109-118.

Nikmah, A., Rudibyani, R. B., \& Efkar, T. (2018). Efektivitas Discovery Learning untuk Meningkatkan Kemampuan Berpikir Kritis dan Penguasaan Konsep Asam Basa Arrhenius. Jurnal Pendidikan Dan Pembelajaran Kimia, 7(2).

Oktaviana, I. A., Saputro, A. N. C., \& Utami, B. (2016). Upaya Peningkatkan Kemampuan Berpikir Kritis Dan Prestasi Belajar Siswa Melalui Penerapan Model Pembelajaran Problem Based Learning (Pbl) Dilengkapi Modul Pada Materi Kelarutan Dan Hasil Kali Kelarutan Kelas XI SMA Negeri 1 Gondang. Jurnal Pendidikan Kimia, 5(1), 143-152.

Redhana, I. W. (2015). Liliasari. 2008. Program Pembelajaran Keterampilan Berpikir Kritis pada Topik Laju Reaksi untuk Siswa SMA. Jurnal Forum Kependidikan, 27(2), 103-112.

Sugiono, M. P. K., \& Kuantitatif, P. (2007). kualitatif dan R\&D. Bandung: Alfabeta.

Sujana, A. (2014). Pendidikan IPA teori dan praktik. Sumedang: Rizal Nur.

Sujatmika, S., Hasanah, D., \& Hakim, L. L. (2018). Effect of quantum learning model in improving creativity and memory. Journal of Physics: Conference Series, 1006(1), 12036.

Surya, M. (2014). Strategi Kognitif. Bandung: Alfabeta.

Susilo, A. B. (2012). Pengembangan model pembelajaran IPA berbasis masalah untuk meningkatkan motivasi belajar dan berpikir kritis siswa SMP. Journal of Primary Education, 1(1).

Widjajanti, D. B. (2011). Problem based learning dan contoh implementasinya. Makalah Universitas Negeri Yogyakarta.

Zarita, S. S., Halim, A., \& Syukri, M. (2015). Dampak Pembelajaran Problem Based Learning (Pbl) Dengan Pendekatan Saintifik Terhadap Berpikir Kritisdan Sikap Siswa Pada Pembelajaran Fisika. Jurnal Pendidikan Sains Indonesia, 3(2), 96-104. 